\title{
THE EFFECT OF MOTIVATIONAL INTERVIEWING INTERVENTION ON MOTIVATION AND ADHERENCE TO ANTIRETROVIRUS THERAPY IN PEOPLE LIVING WITH HIV/AIDS IN MAUMERE, EAST NUSA TENGGARA
}

\author{
Pasionista Vianitati, Imelda Manurung, Sabina Gero \\ Graduate Program in Nursing, Faculty of Health Sciences, \\ Universitas Nusa Nipa Maumere, East Nusa Tenggara
}

\begin{abstract}
Background: Adherence is an essential key to the effectiveness of antiretroviral (ARV) therapy. Motivational interviewing intervention is a method of therapy to enhance intrinsic motivation in order to make behavior changes. This study aimed to examine the effect of motivational interviewing intervention on motivation and adherence to ARV therapy in people living with HIV/AIDS in Maumere, East Nusa Tenggara.

Subjects and Method: This was a quasi experiment with pre and post test. The study was conducted in Maumere, East Nusa Tenggara, Indonesia. A sample of 40 people living with HIV/AIDS (PLWH) was selected randomly. The dependent variables were motivation and adherence to ARV therapy. The independent variable was motivational interviewing intervention. The data were collected by questionnaire and analyzed by $\mathrm{t}$ test and Wilcoxon test.

Results: Motivation on ARV therapy was higher after intervention (mean=42.50; $\mathrm{SD}=3.69)$ than before (mean $=38.45 ; \mathrm{SD}=4.186)$ and it was statistically significant $(\mathrm{p}=$ 0.010). ARV therapy adherence in PLWH after intervention (mean=3.85; SD=0.366) was higher than before (mean=3.10; $\mathrm{SD}=1.071)$ and it was statistically significant $(\mathrm{p}=$ 0.010).

Conclusion: Motivational interviewing intervention increases motivation and adherence to ARV therapy in PLWH.

Keywords: motivation, adherence, motivational interviewing intervention, antiretrovirus therapy

\section{Correspondence:}

Pasionista Vianitati. Graduate Program in Nursing, Faculty of Health Sciences, Universitas Nusa Nipa Maumere, East Nusa Tenggara. Email: pasionistaviani@gmail.com. Mobile: 081239454185.
\end{abstract}

